\title{
Application of Remote Sensing Methods in Research of Nearshore Sandbars, Curonian Spit, Lithuania
}

\author{
Rasa JANUŠAITE ${ }^{1}$, Viktoras KARALIŪNAS ${ }^{1}$, Linas BEVAINIS $^{2}$ \\ ${ }^{1}$ Nature Research Centre, Akademijos str. 2, LT-08412, Vilnius, Lithuania \\ ${ }^{2}$ Vilnius University, Institute of Geosciences, M. K. Čiurlionio str. 21/27 LT-03101, \\ Vilnius, Lithuania \\ rasa.janusaite@gamtc.1t, viktoras.karaliunas@gamtc.lt, \\ linas.bevainis@gf.vu.lt
}

\begin{abstract}
Nearshore sandbars are extremely dynamic morphological features of sandy coasts, containing large volume of sand, important in sediment exchange between the beach and the nearshore. To understand dynamics of these underwater sand ridges regular and frequent observations of their cross-shore and longshore structure are required. Bathymetric surveys in the nearshore are limited to calm weather conditions and are usually conducted using profiling teqnique. For these reasons, optical remote sensing methods are often applied to study sandbar morphodynamics. In this study UAS flights and echo sounding surveys were performed in the nearshore of the Baltic Sea to assess possibilities of UAS imagery for identification of nearshore morphology changes. High spatial resolution images across surveyed bathymetric nearshore profiles were taken. Analysis of obtained images allows to evaluate morphodynamic state and longshore migration of nearshore sandbars, assist in determining structure of bar zone in the nearshore cross-shore profiles. Application of this technology is also valuable for post-storm nearshore monitoring.
\end{abstract}

Keywords: neashore bar, remote sensing, UAS, bar monitoring, coastal morphodynamics, Baltic Sea

\section{Introduction and background}

Nearshore sandbars are extremely dynamic underwater sand ridges containing large volumes of sand which is important in sediment exchange between the nearshore and the subaerial beach (Aagaard et al., 2008). These accumulations of sand safeguard beaches by causing waves to dissipate (Price et al., 2014; Fernandez-Mora et al., 2015; Dubarbier et al., 2015). Sandbar morphological variability has great influences on circulation of nearshore currents which is important for distribution of pollutants, nutrients and sediment in the nearshore zone (de Shipper et al., 2014). Although understanding of sandbar behavior might be significant for many objectives their morphological variability and processes controlling their generation and dynamics remain not completely understood (Di Leonardo and Ruggiero, 2015; Kim et al., 2017). 
To fully investigate these morphological features gathering of data about bar size and depth parameters, plan view shape, cross-shore and alongshore position of the bar crest is required. In early studies of sandbar morphodynamics this data was mainly collected during in situ bathymetric surveys and laboratory experiments. Field measurements at the time were limited by technological and environmental factors. Advances in technology improved capabilities of in situ measurements but it remained inefficient, time-consuming and environmentally constrained (Gao, 2009; Dierssen and Theberge, 2014). In situ measurements strongly depend on weather conditions and hardly might be implemented under high energy waves in the nearshore. This also determines seasonal limitations to perform field measurements. Although echo sounding surveys are an important and reliable source of data for research of nearshore bars, due to previously discussed constraints it is usually performed using cross-shore profiling technique. Data gathered by applying this technique might be good for studies of sandbar cross-shore dynamics, but it is limited to detect alongshore bar structure.

In this context, remote sensing methods are suitable solution to overcome these shortcomings. Optical remote sensing techniques have been employed in sandbar research for over a century now (Roman-Rivera and Ellis, 2019) since aerial photography became a part of nearshore studies. This method was applied in the studies of sandbar morphodynamics (Goldsmith et al, 1982; Bowman and Goldsmith, 1983; Aagaard, 1991) and migration (Shand et al., 1999; Gefelbaum and Brooks, 2003; Aleman et al., 2013; Aleman et al., 2017) or in descriptive sandbar researches (Short, 1975), especially before other remote sensing methods were introduced into nearshore geomorphology. Aerial imagery is an irreplaceable source of data for long-term studies of bar dynamics (Moore et al., 2003; Aleman et al., 2017) because other historical data is rarely available. Nowadays aerial photography is usually used as a source of additional information to determine morphological structure of nearshore bars along the coast and their morphometric parameters.

In the 80 's introduction of video monitoring stated a new era in the studies of sandbar morphodynamics. This technology, based on long time exposure images generated by a system of stationary mounted cameras and main computer, gained recognition in scientific community through Argus system (Holman, 2007). It became a powerful tool for development of sandbar morphodynamic evolution models (Lippmann and Holman, 1990; Ranashinge et al., 2004; Price and Ruessink, 2011; Van de Lageweg et al., 2013), evaluation of longshore and cross-shore migration of the bars (Ruessink et al., 2000; Konicki and Holman, 2000; Van Enckevort and Ruessink, 2003; Ruessink et al., 2009) or a possible alternative to derive nearshore bathymetry (Aarninkhof et al., 2005). Although video monitoring allows to evaluate variety of sandbar characteristics over a wide range of hydrodynamic conditions, it is limited to up to few kilometers long nearshore sectors and is not applicable in a larger spatial scale.

During the last decade meso and high spatial resolution multispectral and hyperspectral satellite imagery providing plenty of possibilities in the research of coastal environments has been developed. It might be employed to extract morphological characteristics of bars or map shallow water bathymetry in large spatial scales (RomanRiviera and Ellis, 2019). However, only a few studies devoted to investigation of bar morphodynamics using satellite imagery (Lafon et al., 2004; Athanasiou et al., 2018) exist so far.

Although variety publicly available remote-sensed material is present, collection of data to study bars across the Baltic Sea coast of Lithuania is problematic. Resolution of publicly available historical spaceborne satellite data is too low to detect complex bar 
morphologies accurately. Raster orthophotographic maps generated by national institutions of Lithuania are updated only once in three years. However, most of the nearshore studies evidence that bars might evolve in a matter of weeks or days (Lippmann and Holman, 1990). For this reason, images of higher temporal frequency are required to determine spatial and temporal variability of these morphologies. It can be done by employing technology of aerial mapping with unmanned aerial system (UAS). Previous studies unraveled advantages of imagery obtained by UAS in the studies of coastal geomorphology, mainly for research of beach morphodynamics (Brunier et al., 2016; Turner et al., 2016; Casella et al., 2016; Yoo and Oh, 2016) and river bars (Watanabe and Kawahara, 2016), but to our knowledge there was no earlier studies dedicated to UAS application to detect nearshore bars.

Based on motivation described above, this study aims to assess possibilities of UAS technology to detect and evaluate morphodynamics of nearshore sandbars in the Lithuanian section of the Curonian spit. Acoustic and UAS-based optical remote sensing techniques were used to achieve this goal. Illustrations of possible analysis of bar morphodynamics using drone imagery are given in results section.

\section{Study area}

Study region is situated along the southeast Baltic Sea coast in Lithuanian section of the Curonian Spit, which stretches from Nida settlement to Klaipeda port for $51 \mathrm{~km}$ (Fig. 1). Subaerial section of Baltic Sea coast in the Curonian Spit is characterized by beachforedune system. Beaches are 30-80 m wide and foredune height ranges from 6 to $16 \mathrm{~m}$ (Jarmalavičius et al., 2015; Žilinskas et al., 2018). Beaches are composed of fine and medium sand. Baltic Sea coast in the Curonian spit is exposed to predominant west, south-west and north-west winds. Wind-generated waves of the same directions with 0.7 - $1.0 \mathrm{~m}$ medium height are dominant (Jakimavičius et al., 2018). Underwater slope of the Curonian Spit is defined by a multiple bar system. Bar zone is $250-750 \mathrm{~m}$ wide and consists of $2-5$ bars. Nearshore slope in the bar zone varies from 0.009 to 0.014. Bars are composed of fine sand whereas troughs are made of coarser sediment.

Research was conducted at sites of Baltic Sea nearshore surveillance performed by Nature Research Centre. It is implemented at 17 nearshore cross-shore profiles across the Curonian Spit and at $500 \mathrm{~m}$ wide nearshore section in Nida. UAS flights were performed at 4 of those sites: Smiltynè, Juodkrantè, northern beach of Nida settlement and southern beach of Nida settlement. Main recreational zones of the Lithuanian section of the Curonian Spit are located in these sites.

Smiltyne site is characterized by widest beaches in the study area, reaching up to 70 $\mathrm{m}$ width, made of fine sand (Jarmalavičius et al., 2013). About $300-400 \mathrm{~m}$ wide bar zone at Smiltyne is composed of $2-5$ small bars. Juodkrante beaches are narrower ( $30-$ $50 \mathrm{~m}$ wide) and consist of coarser material than those in Smiltyne (Jarmalavičius et al., 2013). Nearshore at Juodkrante is typically characterized by a triple bar system, constituting $500-750 \mathrm{~m}$ wide bar zone. Nida beaches reaches $40-60 \mathrm{~m}$ width and are composed of medium-grained sand (Jarmalavičius et al., 2013). Bar zone at Nida is 450 - $650 \mathrm{~m}$ wide and consists of $2-3$ bars with large outer bar which relative height reaches up to 5 meters. 


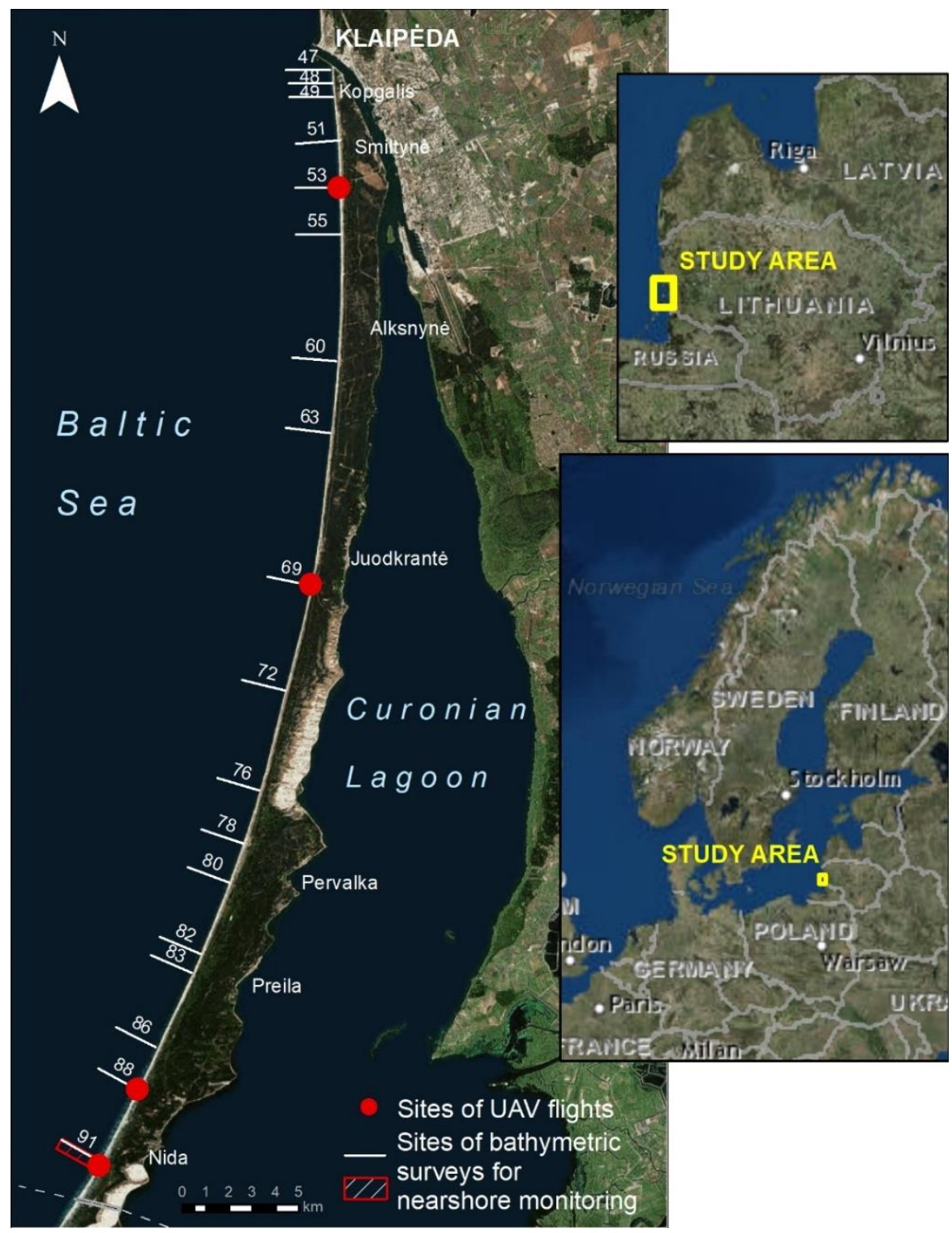

Fig 1. Study area. 


\section{Methods}

\subsection{UAS surveys and image processing}

UAS surveys were conducted on $12^{\text {th }}$ of October in 2018 , on $26^{\text {th }}$ of January in 2019 and on $27^{\text {th }}$ of April in 2019 in the southern beach of Nida. Flights were carried under different hydrodynamic conditions - autumn and spring, when sea was calm and wave energy was low and in the middle of stormy winter season under moderate energy waves. At other study sites flights were performed only on $12^{\text {th }}$ of October in 2018.

They main surveying device was drone DJI INSPIRE 1 with Zenmuse X3 camera (Fig.2). Main characteristics of UAV system used in this study are given in Table 1.

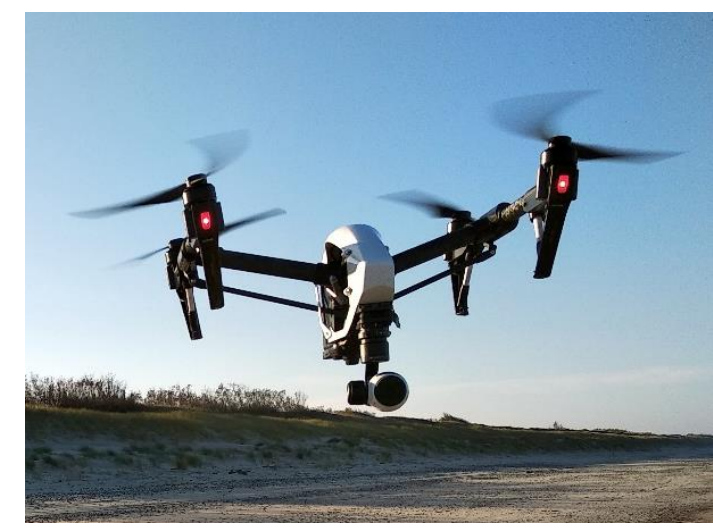

Fig 2. DJI INSPIRE 1 UAV system used in this study.

Table 1. Specifications of UAV system.

\begin{tabular}{ll}
\hline Item & Specification \\
\hline Weight & $3060 \mathrm{~g}$ \\
Wind Speed Resistance & $10 \mathrm{~m} / \mathrm{s}$ \\
Flight Time & Approx. $18 \mathrm{~min}$ \\
Operating temperature & -10 to $40{ }^{\circ} \mathrm{C}$ \\
Speed & $79 \mathrm{kph}($ ATTI mode, no wind) \\
\hline
\end{tabular}

The flight missions were planned using the mobile app Pix4Dcature. This mobile app helped to define the size of a mission area and customize mapping parameters like image overlap, camera angle and flight altitude according to our needs. Missions were executed in 400 - $1100 \mathrm{~m}$ long and 150 - $350 \mathrm{~m}$ wide coastal segments.

After the missions, the data was transferred to photogrammetric software Pixprocessing, where full resolution images were analysed using advanced tools.

Pixprocessing is based on automatically finding thousands of common points between images. When 2 or more keypoints on overlapped images are found to be the same, the software is able to match keypoints. Then each group of correctly matched keypoints were generated to one 3D point cloud. The more keypoints there are, the more 
accurately 3D point cloud can be computed. Very important rule is to maintain high overlap between the images.

The recommended overlap for most cases is at least $75 \%$ frontal overlap (with respect to the flight direction) and at least $60 \%$ side overlap (between flying tracks). It is recommended that the camera would be maintained as much at a constant height over the terrain/object as possible to ensure the desired ground sample distance (GSD). In our case $85 \%$ frontal overlap and $70 \%$ side overlap was used. As a result, 6 orthomosaics with the GSD 5cm/pixel were created.

\subsection{Echo sounding surveys}

Bathymetric surveys were conducted on $12^{\text {th }}$ of October in 2018 parallel to UAV flights and on $18^{\text {th }}$ of May in 2019. Topography of sea bottom was scanned with Humminbird Helix 9 SI GPS dual beam echo sounder. Surveying was carried out using cross-shore profiling technique up to $8 \mathrm{~m}$ depth. Bathymetric data was processed with Reef Master 2.0 and ArcGIS 10.3 software.

In areas shallower than $0.5 \mathrm{~m}$ depth echo sounding data is inaccurate, so parallel to bathymetric measurements topographic surveys with GPNS (Topcon HiPer SR) were carried out in this nearshore area. Later nearshore cross-shore profiles generated from echo sounding data were adjusted based on GPNS data.

\section{Results}

\subsection{Identification of bar morphology}

Obtained UAS images allowed to evaluate morphology of nearshore bars, which is an expression of bar-generating hydrodynamic and lithodynamic processes. Beach morphodynamic states of widely accepted Australian morphodynamic model (Wright and Short, 1984) and morphological types of nearshore bars proposed by Wijnberg and Kroon (2002) have been distinguished in study sites. Types were identified based on position and shape of the bar crest. It can be located at the brightest pixels of an image. Examples of identified bar morphologies are given in Fig.3.

Southern beach of Nida site. On $12^{\text {th }}$ of October in 2018 three sandbars in this site were present. Inner bar was in transverse bar and rip state (TBR)and of shore-attached bar morphology (Fig. 3) with $140 \mathrm{~m}$ distance between consecutive horns and cross-shore amplitude up to 40 meters. Second bar exhibited morphology of alongshore bar and through state (LBT) or of two-dimensional alongshore bar.

Northern Nida beach site. At this site three alongshore bars were observed. Inner bar was in rhythmic bar and beach state (RBB) and exhibited morphology of threedimensional longshore bar (Fig. 3). Rhythmic morphologies of inner bar at northern beach of Nida had less expressed undulating patterns than those at southern Nida beach with alongshore spacing equal to 280 meters.

Smiltyne site. Inner bar was in rhythmic bar and beach state (RBB) and was characterized by morphology of three-dimensional alongshore bar (Fig. 3). Inner bar horns were smaller with shorter alongshore distances ranging from 60 to 100 meters than in other study sites. 

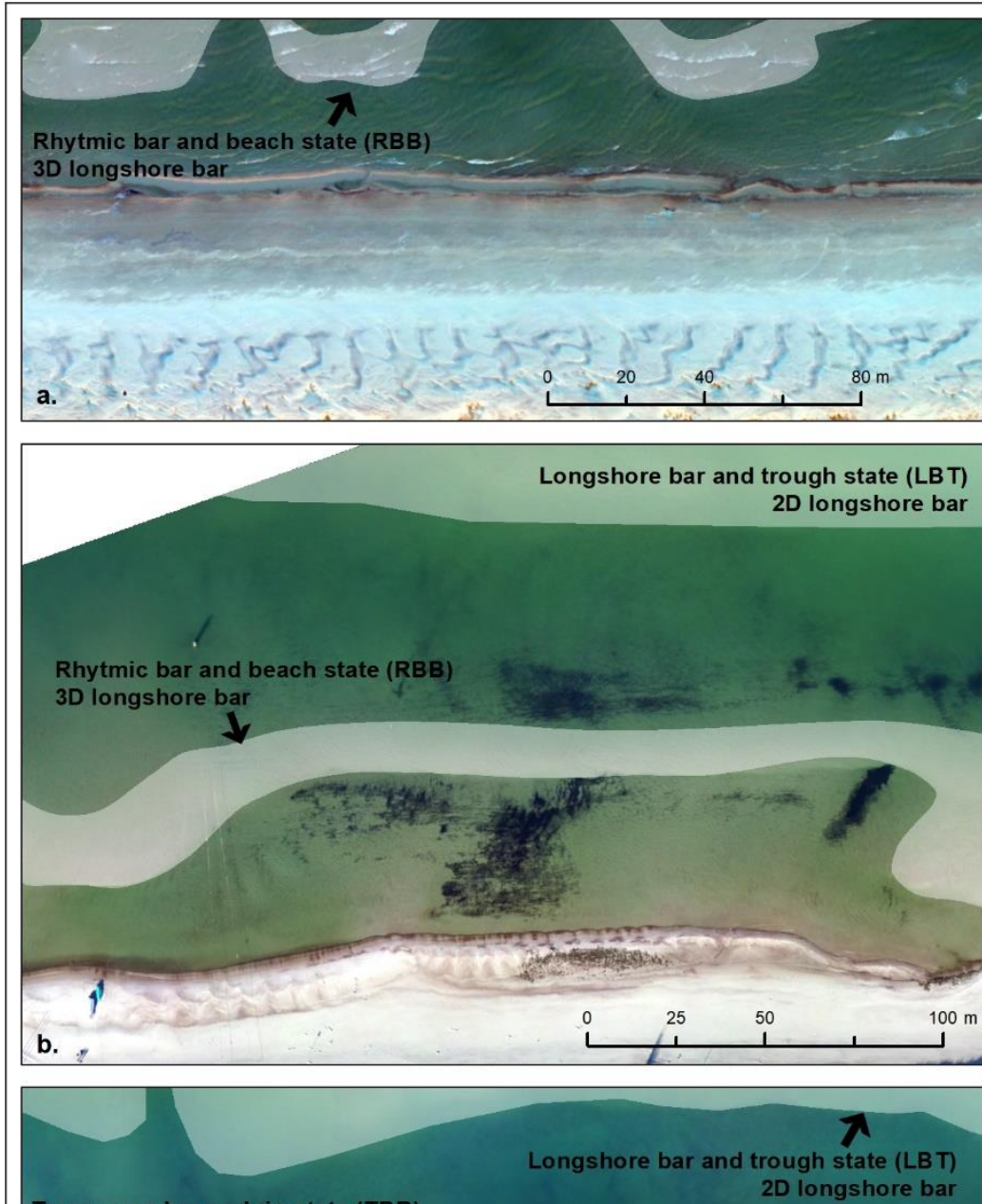

Transverse bar and rip state (TBR)

Shore-attached bar 1

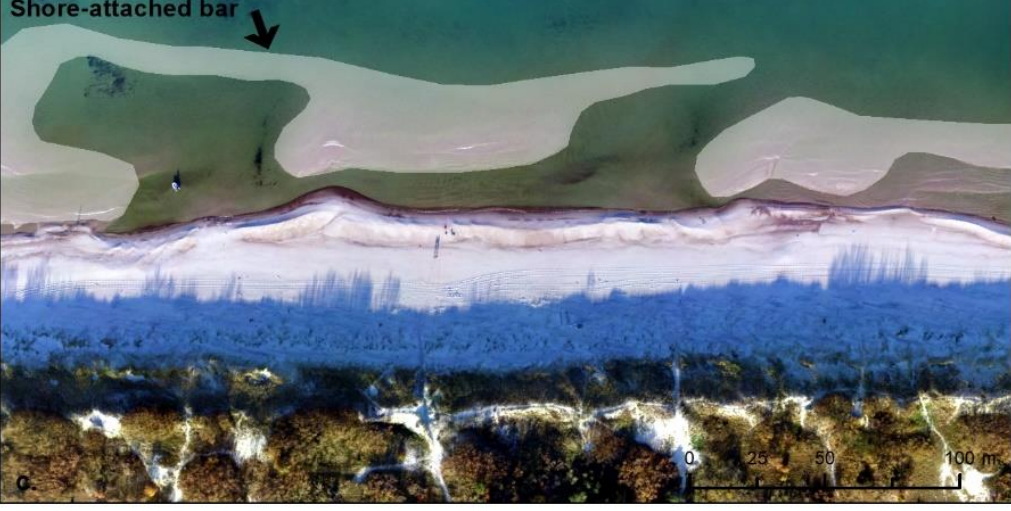

Fig 3. Morphological types of nearshore bars (according to Wijnberg and Kroon, 2002) and morphodynamic states (according to Wright and Short, 1984) in UAS imagery: a - Smiltyné, $\mathrm{b}$ - northern beach of Nida, $\mathrm{c}$ - southern beach of Nida. 


\subsection{Analysis of morphology changes}

Repeated UAV flights at southern beach of Nida site enabled evaluation of nearshore morphology changes. According to beach morphodynamic state models, up-state transitions of bars occur under high energy conditions and down-state transitions occur under lower energy conditions (Wright and Short, 1984; Lippmann and Holman, 1990).
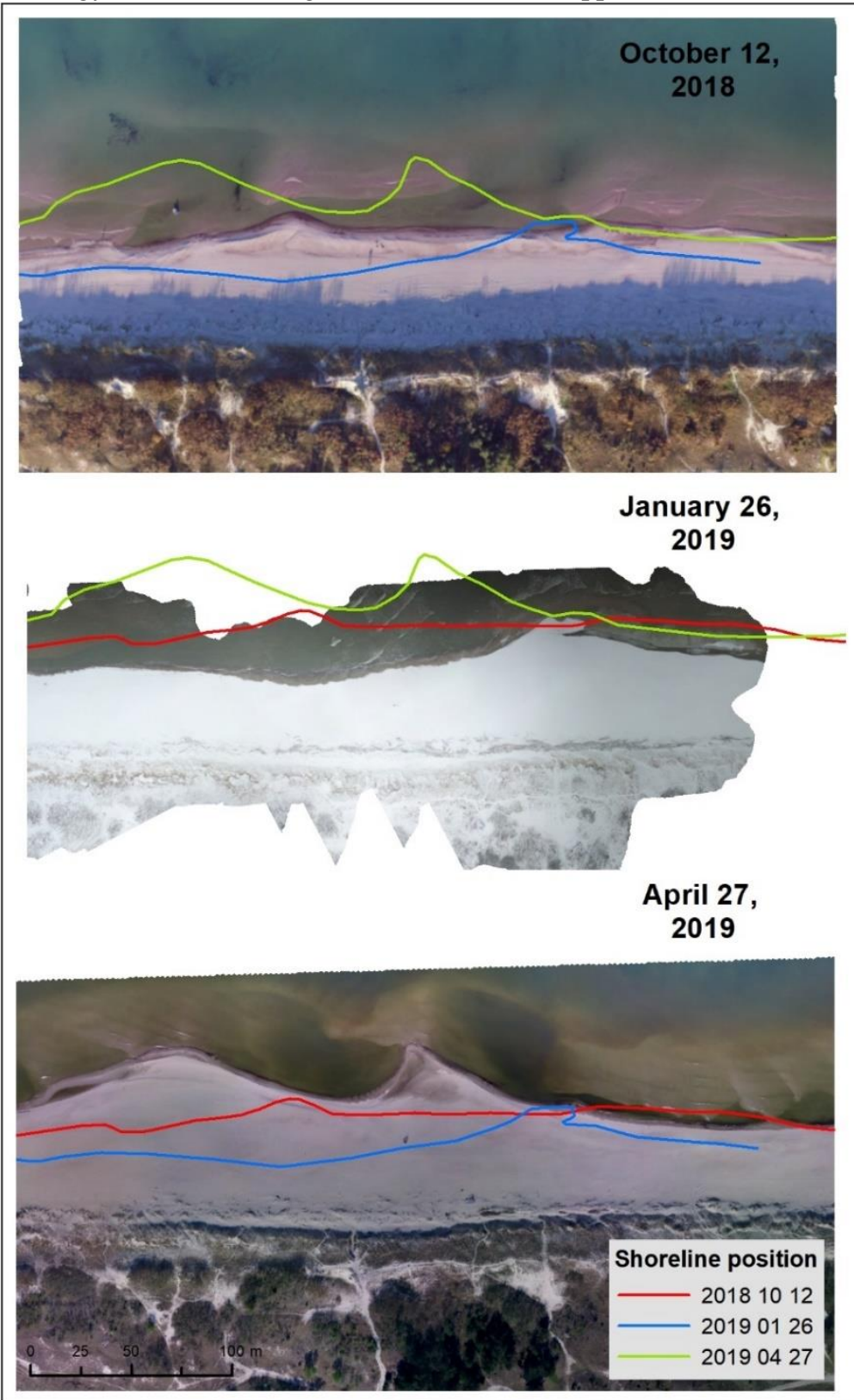

Fig 4. UAS orthomosaics at southern beach of Nida site. 
Although between sampling dates in October and January several storms passed and lower energy conditions set in before the flight in April, morphodynamic state of the inner bar remained unchanged. Horns of the inner bar were reshaped at the southern part of study site, but it was impossible to quantify those changes because data quality in orthomosaic of $26^{\text {th }}$ of January remained poor despite the efforts to eliminate waves in the images.

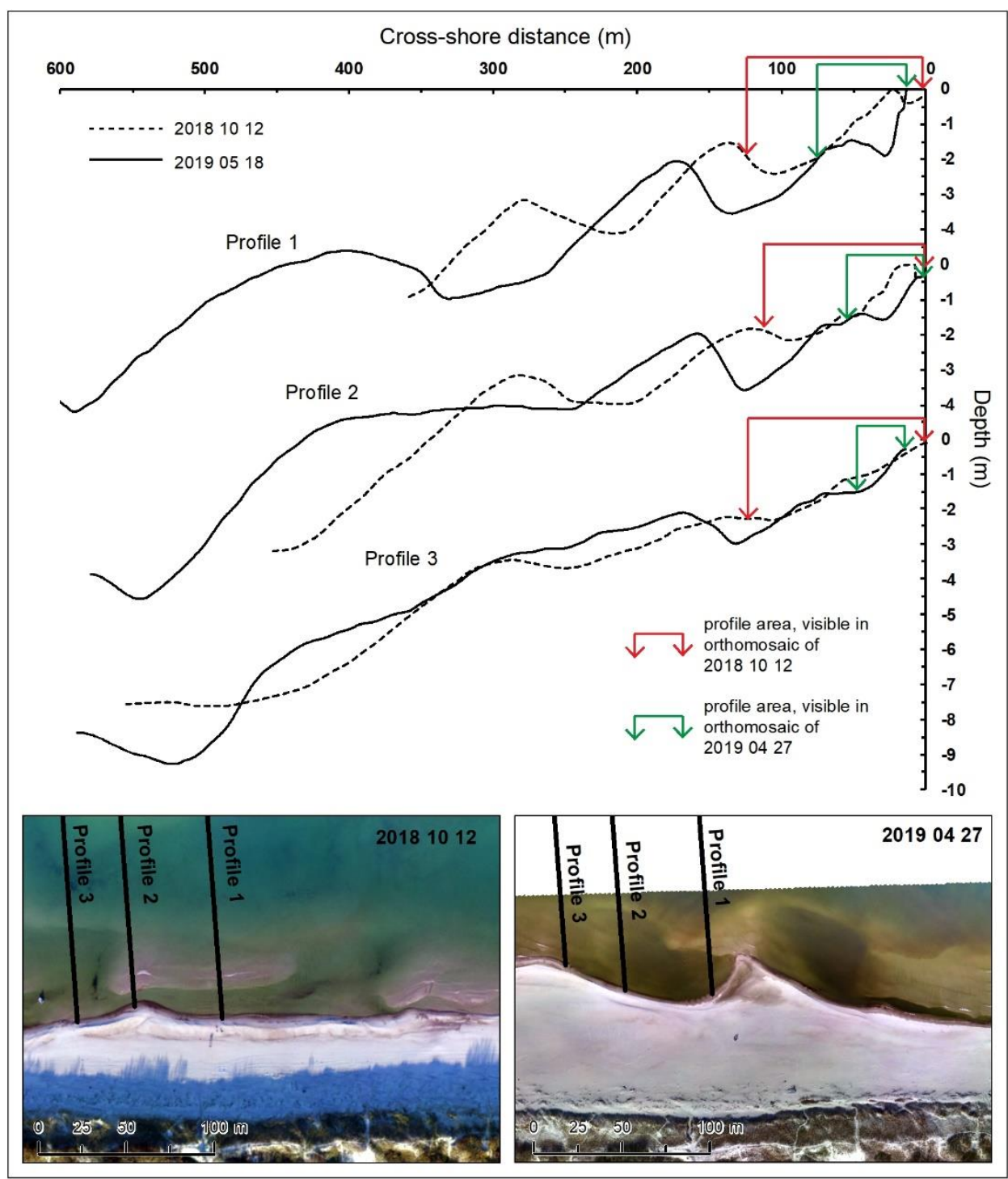

Fig 5. Nearshore cross-shore profiles in polygon of Nida in 20181012 and 20190518 and their locations in UAS-acquired orthomosaics.

Coupled behavior between inner bar, shoreline and the beach was visible during sampling period (Fig. 4). At the northern part of the study area where inner bar horn 
remained welded to the shoreline, the latter was more stable, and rates of coastal erosion and accretion was smaller than in southern part of the study area where transition of the inner bar horns occurred. Between October and January shoreline retreated up to $35 \mathrm{~m}$ in the area where rhythmic morphologies of the inner bar were reshaped and only up to 15 $\mathrm{m}$ in the area where horns of the inner bar were stable. Between January and April shoreline recovered up to $40 \mathrm{~m}$ in the unstable and up to 10 meters in the stable section.

Besides aerial imagery, cross-shore profiles obtained from echo sounding data are a significant tool for analysis of bar dynamics. Profiles extracted at the horn of rhythmic bar, bay or rip channel acquire different shapes, resulting in an open space for interpretations. As shown in Figure 5, shape of nearshore profiles might clearly vary even though alongshore distance between them is only 30-50 m. Additional information about nearshore morphology is required to read profile data correctly. UAS-acquired orthomosaics can provide this information by giving possibility to identify different bar morphologies in the area where profile was extracted.

\section{Discussion and conclusions}

Roman-Rivera and Ellis (2019) distinguishes three criteria for research methods applied in bar morphology studies, including possibility to easily identify bar shape and position of the bar crest over a range of alongshore distances and collect data over a range of hydrodynamic conditions. Here criteria for satisfying sampling period could be added. Although monitoring of nearshore morphology might be implemented using traditional in situ measurements, it does not meet most of these criteria: spatial extent of in situ measurements is usually limited in three-dimensional alongshore scale and measurements can only be performed in calm weather conditions what restricts data collection over variety of hydrodynamic conditions and frequency of sampling. Echo sounding could be replaced by bathymetric Lidar technology, but the high cost prohibits short-term sampling using this technology (Casella et al., 2016). Imagery acquired from satellite sensors enables research of bar morphology at large spatial scales. Quality of satellite images strongly depends on atmospheric and hydrodynamic conditions. Moderate to high energy waves and cloud cover often make position of the bar unidentifiable in satellite images. For this reason, satellite imagery can be used only for bar studies under low energy conditions. UAS-based remote sensing seems to be a proper solution to overcome shortcomings inherent to other methods of data collection. This study unravels the following advantages of UAS technology in the studies of bar morphodynamics:

1) Bar plan view shape can easily be identified in high resolution UAS images. Main models of bar morphodynamics is applicable to classify nearshore morphology in obtained images.

2) Alongshore position of the bar crest can be distinguished across entire study area, so both cross-shore and alongshore migration of bar morphologies can be determined.

3) Data can be collected over variety of hydrodynamic conditions. Modern software tools enable possibility to reduce noise of wave breaking in obtained images. However, quality of images remains poor after wave removal if other factors controlling quality of data (strong wind, precipitation) emerges at the time of the flight. 
4) Data can be collected any time needed and in short-term time intervals. This feature makes UAS-based remote sensing a great alternative for post storm nearshore monitoring. Also, UAS flights might be performed parallel to bathymetric surveys in order to fulfill data gaps of echo sounding.

5) Acquired aerial images can be used to map bathymetry of entire study area. A few studies devoted to mapping of river topography (Walter et al., 2011; Legleiter, 2012) unraveled potential of true color aerial imagery to retrieve bathymetry in clear water environment. Alvarez et al. (2018) demonstrated positive results of hybrid bathymetric system composed of UAS photogrammetry and echo sounding in a small water body. Also, a system for estimation of nearshore bathymetry based on celerity of the wave crests in time series UAS imagery has been developed (Holman et al., 2011; Matsuba and Sato, 2018). Brodie et al. (2019) accurately estimated nearshore bathymetry using multicamera UAS with cBathy algorithm (Holman et al., 2013). Although great potential of UAS-based remote sensing to calculate nearshore bathymetry has been demonstrated, methodology for such estimations are still under development and is not yet being applied in investigatory studies of bar morphodynamics.

Although UAS-based remote sensing provides with all advantages described above, it is limited to relatively short coastal segments due to technical limitation to perform long duration flights.

This study of nearshore morphology changes demonstrates that imagery obtained by UAV system can be an insightful tool for short-term nearshore monitoring and research. It is especially valuable for monitoring of influence of specific weather events on nearshore environment when other data is not available. Surveillance system composed of echo sounding and aerial mapping can provide data necessary for research of nearshore bar dynamics in both horizontal and vertical directions if a researcher is interested in a specific coastal area.

\section{References}

Aagaard, T., Kroon, A., Greenwood, B., Hughes, M. (2008). Field observations of nearshore bar formation. Earth Surface Processes and Landforms, 33(7), 1021-1032.

Aarninkhof, S. G. J. (2005). Nearshore subtidal bathymetry from time-exposure video images. Journal of Geophysical Research, 110, C06011.

Alvarez, L., Moreno, H., Segales, A., Pham, T., Pillar-Little, E.,Chilson, P. (2018). Merging Unmanned Aerial Systems (UAS) Imagery and Echo Soundings with an Adaptive Sampling Technique for Bathymetric Surveys. Remote Sensing, 10(9), 1362.

Bowman, D., Goldsmith, V. (1983). Bar morphology of dissipative beaches: An empirical model. Marine Geology, 51(1-2), 15-33.

Brodie, K.L., Bruder, B.L,., Slocum, R.K., Spore, N.J. (2019). Simultaneous Mapping of Coastal Topography and Bathymetry From a Lightweight Multicamera UAS. EEE Transactions on Geoscience and Remote Sensing, PP(99): 1-21.

Brunier, G., Fleury, J., Anthony, E. J., Gardel, A., Dussouillez, P. (2016). Close-range airborne Structure-from-Motion Photogrammetry for high-resolution beach morphometric surveys: Examples from an embayed rotating beach. Geomorphology, 261, 76-88.

Casella, E., Rovere, A., Pedroncini, A., Stark, C. P., Casella, M., Ferrari, M., Firpo, M. (2016). Drones as tools for monitoring beach topography changes in the Ligurian Sea (NW Mediterranean). Geo-Marine Letters, 36(2), 151-163. 
De Schipper, M. A., Reniers, A. J. H. M., Ranasinghe, R., Stive, M. J. F. (2014). The influence of sea state on formation speed of alongshore variability in surf zone sand bars. Coastal Engineering, 91, 45-59.

Di Leonardo, D., Ruggiero, P. (2015). Regional scale sandbar variability: Observations from the U.S. Pacific Northwest. Continental Shelf Research, 95, 74-88.

Dierssen, H. M., Theberge, A. E. (2016). Bathymetry: Assessment. In: Wang, Y (Ed.) Encyclopedia of Natural Resources: Water and Air, Vol 2. Taylor\&Francis, 629-636.

Dubarbier, B., Castelle, B., Marieu, V., Ruessink, G. (2015). Process-based modeling of crossshore sandbar behavior. Coastal Engineering, 95, 35-50.

Gao, J. (2009). Bathymetric mapping by means of remote sensing: methods, accuracy and limitations. Progress in Physical Geography, 33(1), 103-116.

Gelfenbaum, G., Brooks, G. R. (2003). The morphology and migration of transverse bars of the west-central Florida coast. Marine Geology, 200(1-4), 273-289.

Goldsmith, V., Bowman, D. (1982). Sequential Stage Development of Crescentic Bars: Hahoterim Beach, Southeastern Mediterranean. Journal of Sedimentary Petrology, 52(1), 0233-0249.

Holman, R. A., Holland, K. T., Lalejini, D. M., Spanel, S. D. (2011). Surf zone characterization from Unmanned Aerial Vehicle imagery. Ocean Dynamics, 61(11), 1927-1935.

Holman, R. A.,Stanley, J. (2007). The history and technical capabilities of Argus. Coastal Engineering, 54(6-7), 477-491.

Holman, R., Plant, N., Holland, T. (2013). cBathy: A robust algorithm for estimating nearshore bathymetry. Journal of Geophysical Research: Oceans, 118(5), 2595-2609.

Jakimavičius, D., Kriaučiūnienè, J.,Šarauskienè, D. (2018). Assessment of wave climate and energy resources in the Baltic Sea nearshore (Lithuanian territorial water). Oceanologia, 60(2), 207-218.

Jarmalavičius, D., Pupienis, D., Buynevich, I. V., Žilinskas, G., Fedorovič, J. (2015). Aeolian sand differentiation along the Curonian Spit coast, Baltic sea, Lithuania. The Proceedings of the Coastal Sediments, 2015.

Jarmalavičius, D., Žilinskas, G., Pupienis, D. (2013). Observation on the interplay of sea level rise and the coastal dynamics of the Curonian Spit, Lithuania. Geologija, 55(2), 82: 50-61.

Kim, D.-H., Sanchez-Arcilla, A., Caceres, I. (2017). Depth-integrated modelling on onshore and offshore sandbar migration: Revision of fall velocity. Ocean Modelling, 110, 21-31.

Konicki, K., Holman, R. (2000). The statistics and kinematics of transverse sand bars on an open coast. Marine Geology, 169(1-2), 69-101.

Lafon, V., De Melo Apoluceno, D., Dupuis, H., Michel, D., Howa, H., Froidefond, J. M. (2004). Morphodynamics of nearshore rhythmic sandbars in a mixed-energy environment (SW France): I. Mapping beach changes using visible satellite imagery. Estuarine, Coastal and Shelf Science, 61(2), 289-299.

Legleiter, C. J. (2012). Mapping river depth from publicly available aerial images. River Research and Applications, 29(6), 760-780.

Lippmann, T. C., Holman, R. A. (1990). The spatial and temporal variability of sand bar morphology. Journal of Geophysical Research, 95(C7), 11575-11590.

Matsuba, Y., Sato, S. (2018). Nearshore bathymetry estimation using UAV. Coastal Engineering Journal, 60(1), 51-59.

Moore, L. J., Sullivan, C., Aubrey, D. G. (2003). Interannual evolution of multiple longshore sand bars in a mesotidal environment, Truro, Massachusetts, USA. Marine Geology, 196(3-4), $127-144$.

Price, T. D., Ruessink, B. G. (2011). State dynamics of a double sandbar system. Continental Shelf Research, 31(6), 659-674.

Price, T. D., Ruessink, B. G.,Castelle, B. (2014). Morphological coupling in multiple sandbar systems - a review. Earth Surface Dynamics, 2(1), 309321.

Ranasinghe, R., Symonds, G., Black, K., Holman, R. (2004). Morphodynamics of intermediate beaches: a video imaging and numerical modelling study. Coastal Engineering, 51(7), 629655 . 
Román-Rivera, M. A., Ellis, J. T. (2019). A synthetic review of remote sensing applications to detect nearshore bars. Marine Geology, 408, 144-153.

Ruessink, B. G., Pape, L., Turner, I. L. (2009). Daily to interannual cross-shore sandbar migration: Observations from a multiple sandbar system. Continental Shelf Research, 29(14), 16631677.

Ruessink, B., Terwindt, J. H. (2000). The behaviour of nearshore bars on the time scale of years: a conceptual model. Marine Geology, 163(1-4), 289-302.

Shand, R.D., Bailey, D.G., Shepherd, M.J. (1999). An Inter-Site Comparison of Net Offshore Bar Migration Characteristics and Environmental Conditions. Journal of Coastal Research, 15(3), 750-765.

Short, A.D., 1975. Offshore bars along the Alaskan Arctic coast. The Journal of Geology, 83(2), 209-221.

Turner, I. L., Harley, M. D., Drummond, C. D. (2016). UAVs for coastal surveying. Coastal Engineering, 114, 19-24.

Van de Lageweg, W. I., Bryan, K. R., Coco, G.,Ruessink, B. G. (2013). Observations of shoreline-sandbar coupling on an embayed beach. Marine Geology, 344, 101-114.

Van Enckevort, I. M., Ruessink, B. (2003). Video observations of nearshore bar behaviour. Part 2: alongshore non-uniform variability. Continental Shelf Research, 23(5), 513-532.

Walther, S. C., Marcus, W. A., Fonstad, M. A. (2011). Evaluation of high-resolution, true-colour, aerial imagery for mapping bathymetry in a clear-water river without ground-based depth measurements. International Journal of Remote Sensing, 32(15), 4343-4363.

Wijnberg, K. M., Kroon, A. (2002). Barred beaches. Geomorphology, 48(1-3), 103-120.

Wright, L., Short, A. (1984). Morphodynamic variability of surf zones and beaches: A synthesis. Marine Geology, 56(1-4), 93-118.

Yoo, C.I, Oh, T.S. (2016). Beach volume change using UAV photogrammetry Songjung beach, Korea. Arch. Photogramm. Remote Sens. Spatial Inf. Sci., XLI-B8, 1201-1205.

Žilinskas, G., Jarmalavičius, D., Pupienis, D. (2018). The influence of natural and anthropogenic factors on grain size distribution along the southeastern Baltic spits. Geological Quarterly, 62(2), 375-384.

Received December 22, 2019, accepted December 27, 2019 